\title{
Techniques for Assessing the Investment Attractiveness of a Commercial Organization based on Classical Methods of Strategic Economic Analysis
}

\begin{abstract}
Submitted 20/05/19, $1^{\text {st }}$ revision 24/07/19, $2^{\text {nd }}$ revision 30/09/19, accepted 29/10/19
N.A. Prodanova ${ }^{1}$, N.S. Plaskova ${ }^{2}$, V.A. Dikikh ${ }^{3}$, L.V. Sotnikova ${ }^{4}$, L.K. Nikandrova ${ }^{5}$, G.A. Skachko ${ }^{6}$

Abstract:

Purpose: The development of methodological support for assessing the investment attractiveness of a commercial organization, considering modern information requests of stakeholders.

Design/Methodology/Approach: As part of the research, the authors have developed an algorithm for investment attractiveness assessment of a commercial organization by using the scenario method of economic analysis.

Findings: It is proved that the main disadvantages of the existing methods of assessing investment attractiveness are: the lack of strategic orientation of the assessment; ignoring the influence of most external and internal factors of activity; the inability to assess the risk of investing in the analyzed object; the need to compare with the level of investment attractiveness of similar organizations for an objective interpretation of the results.

Practical implications: To eliminate the significant shortcomings of modern methodological support in this area, the authors recommend the use of scenario method of strategic economic analysis in the process of assessing the investment attractiveness of the organization.

Originality/Value: The scenario method of strategic economic analysis proposed by the authors complements the existing approaches with the ability to take into account potential risks when making a far-sighted decision to invest in an organization by combining the results of retrospective analysis and forecasting changes in the quantitative and qualitative characteristics of financial and economic activity.
\end{abstract}

Keywords: Investment attractiveness, strategic economic analysis, method, assessment, algorithm, scenario.

JEL codes: M21; M40; G32.

Article Type: Research study.

\footnotetext{
${ }^{1}$ Plekhanov Russian University of Economics, Moscow, Russia, prodanova-00@mail.ru

${ }^{2}$ Plekhanov Russian University of Economics, Moscow, Russia.

${ }^{3}$ Moscow City Teacher Training University, Moscow, Russia.

${ }^{4}$ Financial University under the Government of the Russian Federation, Moscow, Russia.

${ }^{5}$ Russian Academy of National Economy and Public Administration under the President of the Russian Federation, Moscow, Russia.

${ }^{6}$ Moscow Aviation Institute (National Research University), Moscow, Russia.
} 


\section{Introduction}

In the context of the need to increase the competitiveness of Russian organizations in the world markets, more and more attention is paid to investments. Increasing the efficiency of using economic potential, developing innovations, changing the strategic course in response to the instability of external operating conditions are tasks whose implementation requires significant investments. More often it is about attracting additional financing by taking bank loan or the owner's investment, less frequently is about making a managerial decision regarding the allocation of free internal resources of the organization. In both the first and second cases, it is important to evaluate such a characteristic of a commercial organization as investment attractiveness (Korableva et al., 2019; Nandi and Mistri, 2019; Laužikas and Miliūtè, 2019; Shaitura et al., 2018).

Qualitative analysis of the investment attractiveness of the organization is the basis for making profitable investment decisions, the basis for ensuring reliable interaction between the source and recipient of financing, as well as a tool for the company's activities management in line with the creation of a favorable image for potential investors (Ige, 2019; Molchanov et al., 2017; Shatunova et al., 2019; Ivanova et al., 2019; Turen et al., 2019).

At the same time, the existing system of methods for assessing investment attractiveness does not have a clear structure, what excludes the possibility of its effective practical application (Petrushina, 2015; Kaźmierczyk, 2019; Masood et al., 2019; Movchan and Yakovleva, 2019; Benešová and Hušek, 2019). The main disadvantages of the existing methods of assessing investment attractiveness are:

- the lack of strategic focus of the assessment;

- disregarding the influence of most external and internal factors of activity, including qualitative characteristics;

- $\quad$ inability to assess the risk of investing in the analyzed object;

- the need to compare with the level of investment attractiveness of similar organizations for an objective interpretation of the results.

According to the authors, it is possible to eliminate these shortcomings in the process of assessing the investment attractiveness of the organization by using the scenario method of strategic economic analysis.

\section{Literature Review}

It should be noted that attempts to systematize existing methods for assessing the investment attractiveness of an organization have been made repeatedly. Zlobina (2006) distinguishes among the methods of assessing investment attractiveness methods of financial and economic analysis, the procedure for determining the creditworthiness of the borrower, rating evaluation (Zlobina, 2006; Prakash and 
Garg, 2019; Paptsov and Nechaev, 2019; Puryaev et al., 2019). Nikitina (2005) classifies the existing instruments for investment attractiveness determination by the level of management, namely: at the level of territories, at the level of organization and individual investment projects (Nikitina, 2005). Shaposhnikov (2010) proposed another system of methods for assessing the investment attractiveness of business entities (Shaposhnikov, 2010; Voronkova et al., 2019; Kashirskaya et al., 2019; Havierniková and Kordoš, 2019).

He identifies approaches to the analysis of the studied characteristics based on stock market indicators, official financial statements of the organization, indicators of value added or acceptable investment risks. Any of the proposed classifications can be successfully applied for the purpose of systematizing the methods for assessing the investment attractiveness of an organization, however, the problem of methodological choice that arises before business practices in finding the most relevant way to determine the significance of a particular organization as an investment object remains on the agenda (Frolova et al., 2019; Korableva et al., 2018; Sycheva et al., 2019; Tarman et al., 2015; Magsumov, 2018; Kuznetsova et al., 2019a,b). Given the variety of solutions proposed by the scientific community, in our opinion, the system of methods for assessing investment attractiveness from the point of view of their effective use should reflect information about the advantages and disadvantages of using each of the elements, about their targeting, i.e. about the type of organization for which the shown method will allow to get the most reliable result, about the composition of the necessary information support, forms of output data and the possibilities for their interpretation.

\section{Methodology}

The theoretical basis of the study was the fundamental provisions of economic theory, as well as scientific works of Russian and foreign scientists in the field of economic analysis of investment attractiveness. System analysis, empirical research, principles of formal logic, synthesis and analysis of theoretical and practical material were used as research tools.

\section{Results}

Risks and factors that determine the activity of an economic entity are elements of its investment attractiveness and play a key role in shaping the results of its evaluation. In the process of the methodology development of the scenario method in relation to the assessment of the investment attractiveness of a commercial organization, we have developed the following criteria for the selection of factors:

- Level of uncertainty: The model does not include factors of the fourth level of uncertainty; 
- Materiality: Because of correlation and regression analysis, it is necessary to select the factors that have the closest relationship with the effectiveness trait, as well as to exclude multicollinear features;

- Internal consistency: After reducing the number of calculated scenarios to the minimum possible, check them for possible logical contradictions by expert means.

Scenarios are the integration of possible future developments and the type of response chosen to such developments (Mukanov, 2015). The compilation of various combinations of factor influence and possible levels of risk allows to determine what will be the economic results of economic activity for each alternative of the predicted future (Silalahi and Yuwono, 2018; Dagdilelis, 2018; Dunets et al., 2019; Fedulova et al., 2019; Gradoboev and Tesleva, 2017; Dagaev et al., 2019). This property of the scenario method is able to satisfy the interests of any participants in the investment process in the course of investment attractiveness assessment of the organization in the framework of achieving various goals (Vasilev et al., 2018; Goryushkina et al., 2019a; 2029b). At the same time, the authors believe that the level of investment attractiveness determined by the scenario method is the probability of achieving the required output indicators under given constraints and predicted events. Under the restrictions should be understood the known parameters of the internal and external environment, as well as the required amount of funding, the current state of the organization and trends in its activities, objectively formed over the past period. Among the predicted events it is necessary to include unknown parameters of future development of events formed as a result of uncertainty of various types. Internal technologies of scenario planning implementation can be different:

- building a decision tree (Cherkasova, 2009);

- construction of trends by linear, logarithmic and polynomial methods based on the revealed regression (Kapustina, 2015);

- using the capabilities of modern software (for example, "Script Manager" and "Parameter Selection" MS Excel), etc.

In the process of forming strategic scenarios, the following stages can be distinguished:

1. Identification of risk factors and their significance.

2. Selection of the most significant risk affecting the implementation of the goals in the long term.

3. Creating scenarios and testing their reliability.

4. Calculation of the occurrence probability of each scenario.

5. Analysis of the objective possibility of achieving strategic goals.

6. Adjust scenarios as needed. 
In this case, the organization of the first stage can be performed as follows (Kapustina, 2015):

1. The choice of indicators of strategic risk factors (the expert way).

2. Selection of the resulting indicators.

3. Collection of indicators from reliable sources.

4. Construction of correlation model, analysis of the obtained correlation dependences.

5. Identification of key risk factors.

In the process of practical adaptation of the methodology of the scenario method of strategic economic analysis to assess the investment attractiveness of a commercial organization, the authors developed the following step-by-step algorithm of actions (Table 1). Assessment of investment attractiveness of a commercial organization using a scenario approach, according to the authors, allows to consider both changes associated with internal factors of activity and possible risks associated with external factors (Hasanudin et al., 2019; Slávik et al., 2019).

Table 1. Investment attractiveness evaluation of the organization using the scenario method

\begin{tabular}{|l|l|l|l|}
\hline Stage & Stage contents & $\begin{array}{l}\text { Information } \\
\text { support }\end{array}$ & $\begin{array}{l}\text { Methodological } \\
\text { support and } \\
\text { technical means } \\
\text { of } \\
\text { implementation }\end{array}$ \\
\hline 1. Organizational stage & $\begin{array}{l}\text { Appointment of } \\
\text { responsible persons } \\
\text { for each of the stages, } \\
\text { setting deadlines for } \\
\text { evaluation }\end{array}$ & $\begin{array}{l}\text { Organizational } \\
\text { structure, job } \\
\text { descriptions and } \\
\text { other regulations } \\
\text { of the } \\
\text { organization }\end{array}$ & $\begin{array}{l}\text { According to the } \\
\text { statements of the } \\
\text { internal } \\
\text { regulations of the } \\
\text { organization }\end{array}$ \\
\hline $\begin{array}{l}\text { 2. The definition of constraints } \\
\text { investment } \\
\text { attractiveness } \\
\text { indicators of the } \\
\text { organization }\end{array}$ & $\begin{array}{l}\text { Collection of primary } \\
\text { information. The } \\
\text { participants of the } \\
\text { investment process in } \\
\text { the evaluation are } \\
\text { guided not just by the } \\
\text { output data, but by the } \\
\text { efficiency coefficients } \\
\text { formed on their basis }\end{array}$ & $\begin{array}{l}\text { Target settings of } \\
\text { the potential } \\
\text { source of } \\
\text { investment } \\
\text { financing (state, } \\
\text { investor, creditor, } \\
\text { owner, } \\
\text { organization } \\
\text { management in } \\
\text { case of } \\
\text { reinvestment of } \\
\text { resources): } \\
\text { technical } \\
\text { specification, }\end{array}$ & $\begin{array}{l}\text { Observation, } \\
\text { interviewing, } \\
\text { questioning, etc. }\end{array}$ \\
\hline
\end{tabular}




\begin{tabular}{|c|c|c|c|}
\hline & & $\begin{array}{l}\text { target program, } \\
\text { etc. }\end{array}$ & \\
\hline $\begin{array}{l}\text { 2.2. Analysis of the } \\
\text { current state, dynamics } \\
\text { and trends of } \\
\text { quantitative elements } \\
\text { of the organization's } \\
\text { investment } \\
\text { attractiveness }\end{array}$ & $\begin{array}{l}\text { Formation of input } \\
\text { data about the } \\
\text { remaining current } \\
\text { assets, the state of the } \\
\text { resource base, the } \\
\text { capital structure }\end{array}$ & $\begin{array}{l}\text { Analytical notes, } \\
\text { budgets, financial } \\
\text { statements, etc. }\end{array}$ & $\begin{array}{l}\text { Budgeting, trend } \\
\text { analysis, etc. }\end{array}$ \\
\hline $\begin{array}{l}\text { 2.3. Determination the } \\
\text { of the forecast period } \\
\text { duration }\end{array}$ & $\begin{array}{l}\text { Based on the given } \\
\text { payback period, as } \\
\text { well as the range of } \\
\text { the most reliable } \\
\text { forecast of factor } \\
\text { changes }\end{array}$ & $\begin{array}{l}\text { Target settings of } \\
\text { the funding } \\
\text { source, internal } \\
\text { needs of the } \\
\text { organization, } \\
\text { availability and } \\
\text { quality of } \\
\text { information on } \\
\text { forecasted events }\end{array}$ & $\begin{array}{l}\text { Probability } \\
\text { theory, expert } \\
\text { estimates }\end{array}$ \\
\hline \multicolumn{4}{|c|}{ 3. Factor impact and risk assessment } \\
\hline $\begin{array}{l}\text { 3.1. Definition of } \\
\text { performance indicators }\end{array}$ & $\begin{array}{l}\text { Correlation and } \\
\text { regression analysis }\end{array}$ & $\begin{array}{l}\text { The specifics of } \\
\text { an organization's } \\
\text { activities }\end{array}$ & Expert evaluation \\
\hline $\begin{array}{l}\text { 3.2. Identification of } \\
\text { factors determining the } \\
\text { parameters of the } \\
\text { organization's } \\
\text { activities and the } \\
\text { extent of their } \\
\text { influence }\end{array}$ & $\begin{array}{l}\text { Practical experience of } \\
\text { the company's } \\
\text { management. Factors } \\
\text { can be included in the } \\
\text { consideration at the } \\
\text { request of the source } \\
\text { of investment } \\
\text { financing }\end{array}$ & $\begin{array}{l}\text { Analytical reports } \\
\text { of heads of } \\
\text { financial } \\
\text { responsibility } \\
\text { centers }\end{array}$ & Expert evaluation \\
\hline $\begin{array}{l}\text { 3.3. Classification of } \\
\text { factors }\end{array}$ & $\begin{array}{l}\text { Assessment of the } \\
\text { uncertainty level of a } \\
\text { factor trait, the } \\
\text { duration of its impact } \\
\text { on the effectiveness } \\
\text { trait in order to further } \\
\text { determine the number } \\
\text { of calculated scenarios }\end{array}$ & $\begin{array}{l}\text { Analytical reports } \\
\text { of heads of } \\
\text { financial } \\
\text { responsibility } \\
\text { centers }\end{array}$ & $\begin{array}{l}\text { Expert evaluation, } \\
\text { grouping method }\end{array}$ \\
\hline \multicolumn{4}{|c|}{$\begin{array}{l}\text { 3.4. Selection of the most significant factors to be included in the investment attractiveness } \\
\text { assessment model }\end{array}$} \\
\hline $\begin{array}{l}\text { 3.4.1. Selection of } \\
\text { factors by uncertainty } \\
\text { level }\end{array}$ & $\begin{array}{l}\text { According to the } \\
\text { conducted research, } \\
\text { the use of scenario } \\
\text { method is possible to } \\
\text { predict the factors of } \\
\text { the second and third } \\
\text { levels of uncertainty }\end{array}$ & $\begin{array}{l}\text { Based on the } \\
\text { analytical data } \\
\text { obtained in step } \\
3.2\end{array}$ & Grouping method \\
\hline $\begin{array}{l}\text { 3.4.2. Determination } \\
\text { of the closeness }\end{array}$ & $\begin{array}{l}\text { Selection of the most } \\
\text { significant factors, }\end{array}$ & $\begin{array}{l}\text { Based on the } \\
\text { analytical data }\end{array}$ & $\begin{array}{l}\text { Correlation and } \\
\text { regression }\end{array}$ \\
\hline
\end{tabular}




\begin{tabular}{|c|c|c|c|}
\hline $\begin{array}{l}\text { between factors and } \\
\text { performance indicator }\end{array}$ & $\begin{array}{l}\text { rejection of } \\
\text { multicollinear features }\end{array}$ & $\begin{array}{l}\text { obtained in step } \\
3.2\end{array}$ & analysis \\
\hline $\begin{array}{l}\text { 3.4.3. Identification of } \\
\text { logical contradictions }\end{array}$ & $\begin{array}{l}\text { In the presence of } \\
\text { mutually exclusive } \\
\text { options of } \\
\text { development of } \\
\text { events, it is necessary } \\
\text { to adjust factor } \\
\text { influence on change } \\
\text { of a effectiveness sign }\end{array}$ & $\begin{array}{l}\text { Based on the } \\
\text { analytical data } \\
\text { obtained in step } \\
3.2\end{array}$ & Expert evaluation \\
\hline $\begin{array}{l}\text { 3.5. Preparation of } \\
\text { matrices of possible } \\
\text { outcomes of factor } \\
\text { influence }\end{array}$ & $\begin{array}{l}\text { At the intersection of } \\
\text { the row and column of } \\
\text { the matrix is the } \\
\text { possible value of the } i \\
\text { factor for the period } k\end{array}$ & $\begin{array}{l}\text { Based on the data } \\
\text { obtained in steps } \\
2.3 \text { and } 3.2\end{array}$ & $\begin{array}{l}\text { Summary, } \\
\text { grouping method }\end{array}$ \\
\hline $\begin{array}{l}\text { 3.6. Determination of } \\
\text { the number of scenarios } \\
\text { for the development of } \\
\text { the organization }\end{array}$ & $\begin{array}{l}\text { The total number of } \\
\text { scenarios is } \\
\text { determined by the } \\
\text { basic formula of } \\
\text { combinatorics } \\
\text { applied to all possible } \\
\text { groups of scenarios } \\
\text { of development of all } \\
\text { factors for the entire } \\
\text { period of forecasting }\end{array}$ & $\begin{array}{l}\text { Based on the } \\
\text { analytical data } \\
\text { obtained in step } \\
3.5\end{array}$ & $\begin{array}{l}\text { The basic formula } \\
\text { of combinatorics }\end{array}$ \\
\hline $\begin{array}{l}\text { 4. Preparation of } \\
\text { forecast scenarios }\end{array}$ & $\begin{array}{l}\text { Formation of separate } \\
\text { scenarios based on } \\
\text { specified input } \\
\text { variables for each } \\
\text { individual } \\
\text { combination of all } \\
\text { factors }\end{array}$ & $\begin{array}{l}\text { Based on the } \\
\text { analytical data } \\
\text { obtained in steps } \\
2.2 \text { and } 3.6\end{array}$ & $\begin{array}{l}\text { Budgeting, trend } \\
\text { analysis, } \\
\text { extrapolation, etc. }\end{array}$ \\
\hline \multicolumn{4}{|c|}{ 5. Adjustment of the development strategy of the organization considering the forecasts } \\
\hline $\begin{array}{l}\text { 5.1. Selection of the } \\
\text { most favorable scenario } \\
\text { as a basis for risk } \\
\text { assessment }\end{array}$ & $\begin{array}{l}\text { Determination of the } \\
\text { scenario, the result of } \\
\text { which is the } \\
\text { maximum increment } \\
\text { of business value or } \\
\text { over-fulfillment of } \\
\text { investment } \\
\text { attractiveness } \\
\text { indicators }\end{array}$ & $\begin{array}{l}\text { Analytical data } \\
\text { obtained in steps } \\
2.1 \text { and } 4\end{array}$ & Comparison \\
\hline $\begin{array}{l}\text { 5.2. Assessment of the } \\
\text { risk component of the } \\
\text { investment } \\
\text { attractiveness of the } \\
\text { organization }\end{array}$ & $\begin{array}{l}\text { Determination of the } \\
\text { amount of lost profits } \\
\text { or additional costs } \\
\text { associated with } \\
\text { adverse factor impact } \\
\text { through preparation }\end{array}$ & $\begin{array}{l}\text { Analytical data } \\
\text { obtained in step } \\
5.1\end{array}$ & $\begin{array}{l}\text { Comparison, } \\
\text { summary, } \\
\text { grouping }\end{array}$ \\
\hline
\end{tabular}




\begin{tabular}{|c|c|c|c|}
\hline & $\begin{array}{l}\text { of risk assessment } \\
\text { matrix }\end{array}$ & & \\
\hline $\begin{array}{l}\text { 5.3. Development of } \\
\text { measures to minimize } \\
\text { risks for each specific } \\
\text { scenario }\end{array}$ & $\begin{array}{l}\text { Development and } \\
\text { evaluation of the cost } \\
\text { and effectiveness of } \\
\text { anti-crisis measures }\end{array}$ & $\begin{array}{l}\text { Methodological } \\
\text { reccomendations } \\
\text { for risk } \\
\text { management and } \\
\text { optimization }\end{array}$ & $\begin{array}{l}\text { Expert evaluation, } \\
\text { financial and } \\
\text { operational } \\
\text { leverages, risk } \\
\text { management }\end{array}$ \\
\hline $\begin{array}{l}\text { 5.4. Adjusting scenarios } \\
\text { considering step } 5.1\end{array}$ & $\begin{array}{l}\text { Adjustment of the } \\
\text { organization's } \\
\text { performance based } \\
\text { on the additional } \\
\text { parameters obtained } \\
\text { in step } 5.1\end{array}$ & $\begin{array}{l}\text { Analytical data } \\
\text { obtained in steps } \\
4 \text { and } 5.1\end{array}$ & $\begin{array}{l}\text { Budgeting, trend } \\
\text { analysis, } \\
\text { extrapolation, etc. }\end{array}$ \\
\hline $\begin{array}{l}\text { 5.5. Definition of signal } \\
\text { indicators for each } \\
\text { scenario }\end{array}$ & $\begin{array}{l}\text { In order to ensure the } \\
\text { possibility of rapid } \\
\text { response of } \\
\text { management to the } \\
\text { possible occurrence } \\
\text { of risk events, key } \\
\text { indicators and their } \\
\text { values are determined } \\
\text { for each of the } \\
\text { periods based on } \\
\text { which decisions are } \\
\text { made to carry out } \\
\text { anti-crisis measures - } \\
\text { preparation of the } \\
\text { response matrix }\end{array}$ & $\begin{array}{l}\text { Analytical data } \\
\text { obtained in step } 4\end{array}$ & $\begin{array}{l}\text { Summary, } \\
\text { grouping method }\end{array}$ \\
\hline \multicolumn{4}{|c|}{ 6. Assessment of investment attractiveness of the organization } \\
\hline $\begin{array}{l}\text { 6.1. Determination of } \\
\text { the number of } \\
\text { scenarios, the results of } \\
\text { which correspond to } \\
\text { the indicators of } \\
\text { investment } \\
\text { attractiveness }\end{array}$ & $\begin{array}{l}\text { Comparison of } \\
\text { indicators calculated } \\
\text { based on the results } \\
\text { of the organization's } \\
\text { activities for each of } \\
\text { the scenarios with } \\
\text { indicators of } \\
\text { investment } \\
\text { attractiveness. } \\
\text { Determining the } \\
\text { number of best-case } \\
\text { scenarios }\end{array}$ & $\begin{array}{l}\text { Analytical data } \\
\text { obtained in steps } \\
2.1 \text { and } 5.4\end{array}$ & Comparison \\
\hline $\begin{array}{l}\text { 6.2. Assessment of the } \\
\text { probability of the } \\
\text { relevant scenario } \\
\text { occurrence }\end{array}$ & $\begin{array}{l}\text { The ratio of the } \\
\text { number of optimal } \\
\text { scenarios to the total } \\
\text { number of scenarios } \\
\text { calculated, adjusted } \\
\text { for the number of all } \\
\text { possible scenarios }\end{array}$ & $\begin{array}{l}\text { Analytical data } \\
\text { obtained in steps } \\
3.6 \text { and } 6.1\end{array}$ & Probability theory \\
\hline
\end{tabular}


Accompanying tools of scenario method implementation in this case are methods of financial analysis (horizontal, vertical, trend, etc.), statistics (correlation and regression analysis, construction of time series, index method, etc.), planning (balance, normative, extrapolation, technical and economic calculations, etc.), strategic economic analysis (R-analysis, expert assessments, etc.), probability theory and combinatorics.

\section{Conclusion}

The result of the scenario method of the investment attractiveness analysis of the organization is the probability of occurrence of the relevant scenario of development of its activities, ensuring the achievement of the objectives of the subject of evaluation. There is no need in ranking of value ranges assessment for compliance with the levels of investment attractiveness (low, medium, high), as each of the parties involved in making investment decisions, may determine on the basis of the analysis of how that probability is the optimal from the point of view of possible risks, how representative the sample by values of the factor variables according to which calculation, and if sufficiently the risks assessment and development measures to minimize them conducted.

The proposed adapted scenario method allows to solve the existing problems of methodological support for assessing the investment attractiveness of business, can be used in practice to assess the objects of various organizational and legal forms and activities, to justify tactical, strategic management decisions and forecasts of long-term development of companies that are of interest to different groups of users of information.

\section{References:}

Benešová, D., Hušek, M. 2019. Factors for efficient use of information and communication technologies influencing sustainable position of service enterprises in Slovakia. Entrepreneurship and Sustainability, 6(3), 1082-1094. http://doi.org/10.9770/jesi.2019.6.3(9)

Cherkasova, V.A. 2009. Formation of corporate strategy on the basis of scenario planning. Economic analysis: theory and practice, No. 6, 19-27.

Dagaev, A.M., Novikov, A.V., Afonin, M.V., Maximov, D.A. \& Golubtsova, E.V. 2019. Systems engineering: Tax risk peculiarities in project execution. International Journal of Engineering and Advanced Technology, 8(5), 2226-2230.

Dagdilelis, V. 2018. Preparing teachers for the use of digital technologies in their teaching practice. Research in Social Sciences and Technology, 3(1), 109-121. Retrieved from http://ressat.org/index.php/ressat/article/view/345

Dunets, A., Muhamedieva, A., Sycheva, I., Perepechkina, E., Vakhrushev, I. \& Kulchytskiy, A. 2019. Spatial tourism planning: Using the model of functional and planning complexes. Journal of Environmental Management and Tourism, 10(4), 711-719. doi:10.14505/jemt.v10.4(36).01

Fedulova, I., Ivanova, V., Atyukova, O. \& Nosov, V. 2019. Inclusive education as a basis for 
sustainable development of society. Journal of Social Studies Education Research, 10(3), 118-135.

Frolova, I., Voronkova, O., Islamutdinova, D., Gordeyeva, O., Fedulova, I. \& Zhminko, A. 2019. Ecologization of agroindustrial production: Organizational and economic transformations. Journal of Environmental Management and Tourism, 10(3), 622630. doi:10.14505/jemt.v10.3(35).16

Garnov, A.P., Krasnobaeva O.V. 2013. Investment design: studies manual. Moscow: INFRA-M, p. 254.

Gradoboev, A.V. \& Tesleva, E.P. 2017. Local mechanical stress relaxation of gunn diodes irradiated by protons. Paper presented at the Journal of Physics: Conference Series, 830(1). doi:10.1088/1742-6596/830/1/012133.

Goryushkina, N., Voinova, N., Voronkova, O., Sitnov, A., Shichiyakh, R. \& Gordeyeva, O. 2019a. Theoretical aspects of entrepreneurial education for hospitality industry. Journal of Environmental Management and Tourism, 10(4), 835-841. doi:10.14505/jemt.10.4(36).14

Goryushkina, N.E., Gaifutdinova, T.V., Logvina, E.V., Redkin, A.G., Kudryavtsev, V.V. \& Shol, Y.N. 2019b. Basic principles of tourist services market segmentation. International Journal of Economics and Business Administration, 7(2), 139-150.

Havierniková, K., Kordoš, M. 2019. Selected risks perceived by SMEs related to sustainable entrepreneurship in case of engagement into cluster cooperation. Entrepreneurship and Sustainability Issues, 6(4), 1680-1693. http://doi.org/10.9770/jesi.2019.6.4(9)

Hasanudin, A.I., Yuliansyah, Y., Said, J., Susilowati, Ch., Muafi. 2019. Management control system, corporate social responsibility, and firm performance. Entrepreneurship and Sustainability Issues, 6(3), 1154-1168. http://doi.org/10.9770/jesi.2019.6.3(21)

Ige, O. 2019. Using action learning, concept-mapping, and value clarification to improve students' attainment in ict concepts in social studies: The case of rural learning ecologies. Journal of Social Studies Education Research, 10(1), 301-322.

Ivanova, V., Poltarykhin, A., Szromnik, A. \& Anichkina, O. 2019. Economic policy for country's digitalization: A case study. Entrepreneurship and Sustainability Issues, 7(1), 649-661. doi:10.9770/jesi.2019.7.1(46)

Kapustina, N.V. 2015. Methodology of assessment of strategic and tactical risk factors of modern developing organization. Management of economic systems: electronic scientific journal, No.1, (73). Access mode: https://cyberleninka.ru/article/v/metodologiya-otsenki-strateg-i-taktiches-kihfaktorov-riska-sovremennoy-razvivayuscheysya-organizatsii.

Kashirskaya, L., Voronkova, O., Sitnov, A., Shichiyakh, R., Kudinova, M. \& Sycheva, I. 2019. Rural development through the formation of zonal agro-ecological clusters. Journal of Environmental Management and Tourism, 10(3), 651-659. doi:10.14505/jemt.v10.3(35).19

Kaźmierczyk, J. 2019. Workforce segmentation model: banks' example, Entrepreneurship and Sustainability Issues. 6(4). 1938-1954. http://doi.org/10.9770/jesi.2019.6.4(28)

Korableva, O.N., Kalimullina, O.V., Zaytseva, A.A. \& Larionov, A.I. 2018. Elaboration of database for the subject domain of innovation and economic growth potential. Paper presented at the Proceedings of the 31st International Business Information Management Association Conference, IBIMA 2018: Innovation Management and Education Excellence through Vision 2020, 6065-6073.

Korableva, O.N., Kalimullina, O.V., Mityakova, V.N. 2019. Designing a System for Integration of Macroeconomic and Statistical Data Based on Ontology. Advances in Intelligent Systems and Computing, 998, 157-165. 
Kuznetsova, I.G., Bulyga, R.P., Rakhmatullina, L.V., Titova, S.V., Shichiyakh, R.A. \& Zakirov, R.A. 2019a. Problems and prospects of human capital development in modern russia. International Journal of Economics and Business Administration, $7(2), 164-175$.

Kuznetsova, I.G., Voronkova, O.Y., Nimatulaev, M.M., Ruiga, I.R., Zhuruli, G.N. \& Levichev, V.E. 2019b. Ensuring the national security of agriculture in the digital era through the formation of human capital. International Journal of Economics and Business Administration, 7, 558-569.

Laužikas, M., Miliūtė, A. 2019. Transformational Communication via Evolving Ethical and Moral Norms of Lithuanian Civil Service Organizations. Entrepreneurship and Sustainability, 6(4), 1750-1761. http://doi.org/10.9770/jesi.2019.6.4(14)

Magsumov, T.A. 2018. Vocational school and studying youth in the Russian revolution of 1905. Terra Sebus, 10, 289-313.

Masood, O., Tvaronavičienè, M., Javaria, K. 2019. Impact of oil prices on stock return: evidence from G7 countries. Insights into Regional Development, 1(2), 129-137. https://doi.org/10.9770/ird.2019.1.2(4)

Mukanov, A.H. 2015. Development of scenarios as a basis for strategic planning of production activities in organizations. Bulletin of Omsk University. Series: Economics, No. 2, 103-110.

Movchan, I.B. \& Yakovleva, A.A. 2019. Refined assessment of seismic microzonation with a priori data optimisation. Journal of Mining Institute, 236, 133-141. doi:10.31897/PMI.2019.2.133

Molchanov, N.N., Korableva, O.N., Muraveve, O. \& Galay, N. 2017. Neuromarketing as an innovative approach to market research of consumer behavior. Paper presented at the Proceedings of the 29th International Business Information Management Association Conference - Education Excellence and Innovation Management through Vision 2020: From Regional Development Sustainability to Global Economic Growth, 2489-2499.

Nandi, S. \& Mistri, T. 2019. Rural settlement expansion and its effect on food security in salanpur, west bengal, india. Space and Culture, India, 6(5), 198-214. doi:10.20896/SACI.V6I5.346

Nikitina, V.A. 2005. Assessment of investment attractiveness of large Russian companies. $\mathrm{PhD}$ thesis in Economics: 08.00.05. Moscow, 18.

Paptsov, A. \& Nechaev, V. 2019. Towards to a single innovation space in the agrarian sector of the member states of the eurasian economic union: A case study. Entrepreneurship and Sustainability Issues, 7(1), 637-648. doi:10.9770/jesi.2019.7.1(45)

Prakash, R., Garg, P. 2019. Comparative assessment of HDI with Composite Development Index (CDI), Insights into Regional Development, 1(1), 58-76. https://doi.org/10.9770/ird.2019.1.1(5)

Petrushina, L.O. 2015. The Modern economic prerequisites for the justification of investment attractiveness of the commercial organization. Comp. of reports of the XXV international scientific and practical conference "Problems of modern economy". Novosibirsk: Publishing house CRNS, 180-185.

Puryaev, A.S., Puryaeva, Z.A., Kharisova, A.R. \& Puryaev, A.A. 2019. Investigation and explanation of mathematical tooling for accounting non-economic characteristics during the investment project effectiveness' assessing process. IOP Conference Series: Materials Science and Engineering, 570, 012074. 
https://doi.org/10.1088/1757-899X/570/1/012074

Shaposhnikov, A.A. 2010. Development of a comprehensive mechanism for analysis and evaluation of the investment attractiveness of the organization: thesis abstract of PhD in economics: 08.00.05. Novgorod, 24.

Shatunova, O., Anisimova, T., Sabirova, F. \& Kalimullina, O. 2019. Steam as an innovative educational technology. Journal of Social Studies Education Research, 10(2), 131144.

Shaitura, S.V., Ordov, K.V., Lesnichaya, I.G., Romanova, Y.D. \& Khachaturova, S.S. 2018. Services and mechanisms of competitive intelligence on the internet. Espacios, 39(45).

Silalahi, R. \& Yuwono, U. 2018. The Sustainability of Pancasila in Indonesian Education System. Research in Social Sciences and Technology, 3(2), 58-78. Retrieved from http://ressat.org/index.php/ressat/article/view/364

Slávik, Š., Hagarová, R., Ljudvigová, I., Zagoršek, B. 2019. Business model and team as preconditions of a start-up viability. Entrepreneurship and Sustainability Issues, 6(3), 1204-1227. http://doi.org/10.9770/jesi.2019.6.3(25)

Sycheva, I., Voronkova, O., Vorozheykina, T., Yusupova, G., Semenova, A. \& Ilyin, A. 2019. The main directions of improving the environmental and economic efficiency of regional production. Journal of Environmental Management and Tourism, 10(3), 631-639. doi:10.14505/jemt.v10.3(35).17

Tarman, B., Baytak, A. \& Duman, H. 2015. Teachers' views on an ICT reform in education for social justice. Eurasia Journal of Mathematics, Science and Technology Education, 11(4), 865-874. doi:10.12973/eurasia.2015.1445a

Turen, S., Abdulla, M., Farooq, M.O., Elsoud, M.S.A. 2019. Causes of Non-Performing Loans: The Experience of Gulf Cooperation Council Countries, Entrepreneurship and Sustainability Issues, 6(4), 1955-1974. http://doi.org/10.9770/jesi.2019.6.4(29)

Vasilev, B.U., Grigorev, P.S. \& Shulgenko, V.M. 2018. Configuration and energy supply of promising types of underwater pumping complexes for transportation of hydrocarbons from the shelf. Neftyanoe Khozyaystvo - Oil Industry, (3), 77-81. http://doi:10.24887/0028-2448-2018-3-77-81

Voronkova, O., Sycheva, I., Kovaleva, I., Khasanova, A., Gorovoy, S. \& Vorozheykina, T. 2019. Assessing the environmental impact of the intensification of agricultural production. Journal of Environmental Management and Tourism, 10(3), 697-705. doi:10.14505/jemt.v10.3(35).24

Zlobina, A.Yu. 2006. Methodological approaches for determining the investment attractiveness of the organization: thesis abstract of $\mathrm{PhD}$ in economics: 08.00.05. Irkutsk, 24. 